$1989,38,1$

УДК 541.14

M. LOPP, Malle BERGMANN, O. LILLE

\title{
SYNTHESIS AND ANTIAGGREGATORY ACTIVITY OF A NEW 15-ACHIRAL CARBACYCLIN
}

M. LOPP, Malle BERGMANN, O. LILLE. UUE 15-AKIRAALSE KARBATSUKLIINI SONTEES JA ANTIAGREGATIIVNE TOIME

М. ЛОПП, Малле БЕРГМАНН, Ю. ЛИЛЛЕ. СИНТЕЗ И АНТИАГРЕГАЦИОННАЯ АКТИВНОСТЬ НОВОГО 15-АХИРАЛЬНОГО КАРБАЦИКЛИНА

$S$-configuration of the carbon-15 is a relevant structural feature of natural prostacyclin (I) as a potent antiaggregatory agent [ $\left.{ }^{1}\right]$. In the case of stabilized analogs, for example, carbacyclin (II), the corresponding $R$-isomer is inactive. However, it does not interfere with the action of the $S$-isomer.

To get a new insight into the role of chirality of carbon-15 we synthesized $( \pm)$ 13,14-didehydro-14-cyclohexylcarbacyclin (III) (the scheme).

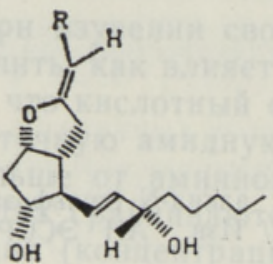

(1)

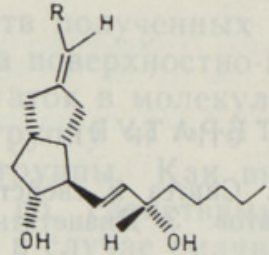

(II)

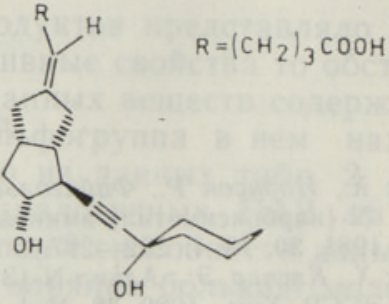

(III)

A remarkable feature of (III) is the achiral carbon-15 if the role of the enantiometric twist conformation can be neglected at a physiological temperature.

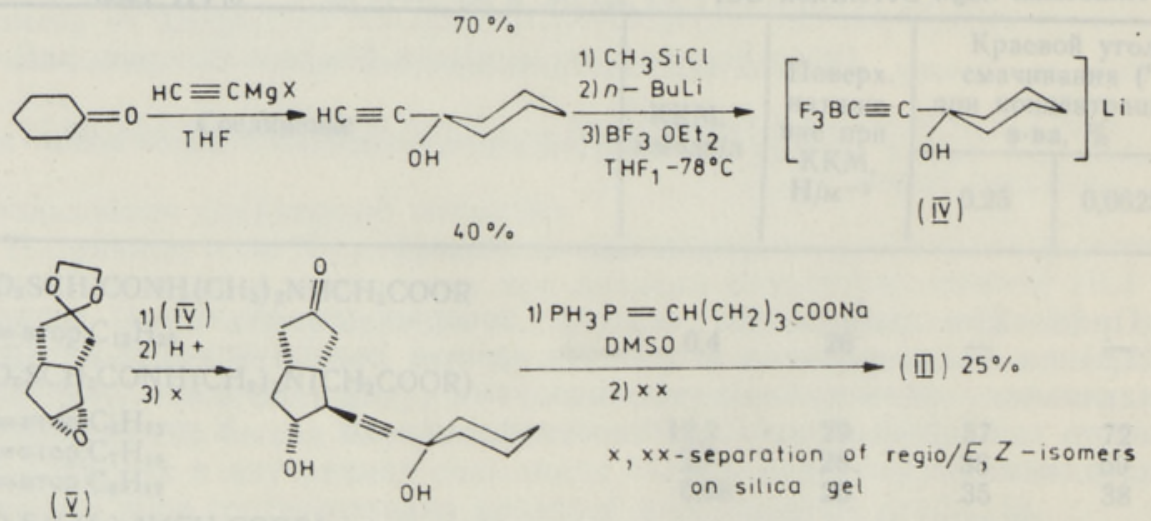

This extremely short scheme consists of the known reactions. The synthesis of the key-intermediate (V) and the role of the borate reagent (IV) in oxirane opening reactions have been described earlier $\left[{ }^{2,3}\right]$. The amounts 
of normal and regioisomeric products in oxirane opening were nearly equal. All intermediates and end products were identified by ${ }^{13} \mathrm{C}-\mathrm{NMR}$ spectra.

The $\mathrm{IC}_{50}$ value for $\mathrm{ADP}$-induced human platelet aggregation was determined as $0.50( \pm 0.005) \mu \mathrm{m}\left(0.040 \mu \mathrm{m}\right.$ for $\mathrm{PGE}_{1}$ as a reference compound). Though this value is about two exponents higher than that of (I), it shows that chirality of carbon-15 is not a strict prerequisite for antiaggregatory activity. This finding simplifies the synthesis of new active analogs since the number of the isomers can be decreased twice.

The authors acknowledge the work of T. Välimäe and $M$. Viigimaa on ${ }^{13} \mathrm{C}$-NMR spectra and platelet aggregation measurement, respectively.

\section{REFERENCES}

1. Floche, L., Böhlke, M., Frankus, E. a. o. Designing prostacyclin analogs // Drug. Research, 1983, 33(11), N 9, 1240-1248.

2. Парве О., Пальс А., Льхмус М., Вялимяэ Т., Лахе Л., Лопп М., Лилле Ю. Синтез простагландинов $F$ и $I$ ряда. 2 . Синтез $( \pm) 13,14$-дидегидро-6,9 9 -метанопростагландина $\mathrm{I}_{2}$ через этиленовый кеталь 2,3-эндо-эпоксибицикло[3.3.0]октан-7-она // Изв. АН ЭССР. Хим., 1985, 34, № 4, 285-291.

3. Кангер Т. П., Лопn М. И., Лилле Ю. Э. Изучение реакции раскрытия оксиранов. 1. Роль трехфтористого бора в реакции алкинилирования бициклических оксиранов // Ж. орг. хим., 1988, XXIV, № 12, 2543-2546.

Academy of Sciences of the Estonian SSR,

Received Institute of Chemistry 